資源と素材 (Shigen - to - Sozai)Vol.122 p.654-658(2006) (C)2006 The Mining and Materials Processing Institute of Japan

\section{報告}

Technical Report

\section{超大型油圧ショベル EX8000 による オイルサンド鉱床開発*}

斎 藤 敏 夫 $^{1}$ 相 原 三 男 $^{2}$ 吉 井 勝 敏 ${ }^{3}$

\title{
Super large Size Excavator EX8000 in Development of Oil Sand Deposit
}

\author{
by Toshio SAITOH ${ }^{\mathrm{a} *}$,Mitsuo AIHARA ${ }^{\mathrm{a}}$ and Katsutoshi YOSHII ${ }^{\mathrm{b}}$
}

a. Engineering Center Mining \& Heavy Equipment Div., Hitachi Construction Machinery Co.,Ltd., Tsuchiura Works 650, Kandatsu-machi, Tsuchiura-shi, Ibaraki-ken 300-0013 Japan (*Corresponding author: FAX +81-29-832-7352 / E-mail t-saitou91@hitachi-kenki.co.jp)

b. Sales Promotion \& Technical Support Dept, Mining \& Heavy Equipment Div., Hitachi Construction Machinery Co.,Ltd., 5-1, Koraku 2-chome, Bunkyo-ku, Tokyo 112-8563 Japan

The major mines around the world are taking the steps for enlargement of the dump truck size to improve the efficiency, and the yearly demand for the 300 ton class dump trucks is increasing year by year.

About $25 \%$ of the total world demand for such 300 ton class dump trucks is predicted to be the demand for the oilsand mines where the demand for the hydraulic shovels looks promising as well.

The super large size excavator EX8000 was developed to meet such demand for the matching shovels for the 300 ton class dump trucks.

The development was carried out based upon the experience from the existing super large size excavators, and emphasized on achieving the unsurpassed reliability and availability that is the absolute necessity for the loading machines in the mines.

Both the first machines, the second machines of EX8000, and the third machines are delivered to the oil Sand mine in Alberta state in Canada. These machines are engaged in digging up the topsoil layer and the oil sand.

KEY WORDS: Excavator, Oil Sand, Mining Machinery, Reliability, Monitoring

$$
\text { 1. はじめに }
$$

今や，鉱物資源に関する話題にはことかかない。世界経済，中 でも中国，インドをはじめとするアジア諸国の発展を背景に資源 需要が高まり,世界の鉱山では増産が続いている。特にエネルギー 資源がクローズアップされ，これまで生産コストが高いため，さ ほど注目されなかったオイルサンドにも関心が集まっている。こ れは, 最近の原油高もあって, 長期的な安定したエネルギー源と しての期待が高まってきているためであると考えられる。オイル サンドの推定可採埋蔵量は, 約 3,000 億バレル (48 兆リットル) と言われ，サウジアラビアを上回る埋蔵量である。

鉱山業界の活況に伴い鉱山機械の需要が急速に伸びている。

2005 年は 2003 年に比べほぼ倍増する勢いである。主要鉱山で 稼働する主な機械の稼働台数を Fig. 1 に示す。露天掘りが普及し た 1960 年代は超大型のドラグラインや電気ショベルを用いた工 法がほとんどであったが, 1980 年代以降は次第に大型化したホ

$* 2006$ 年 8 月 8 日受付 11 月 13 日受理

1. 日立建機 (株) 資源開発システム事業部 開発設計センタ超大型ショ心゙

2. 日立建機 (株) 資源開発システム事業部 開発設計センタ超大型ショベ ル $\mathrm{G}$

3. 日立建機 (株) 資源開発システム事業部 技術部

[ 著者連絡先 ] FAX : 029-832-7352 E-mail : t-saitou91@hitachi-kenki.co.jp

キーワード：油圧ショベル，オイルサンド，鉱山機械，信頼性，モニタリ

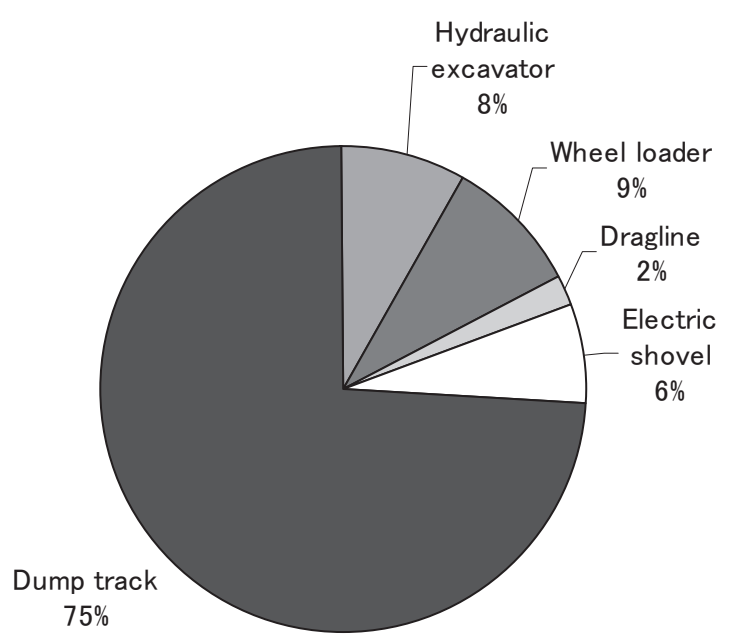

Fig.1 The main machines used in the major mines. (Total number:27206)

イールローダや油圧ショベルなどの積込機とダンプトラックの組 合せが主流となった。

オイルサンドの採掘も他鉱山と同様で，石炭と同じような露天 掘り工法が主である。最近の掘削運搬機械は従来のドラグライン やベルトコンベアシステムに変わり，膨大な広さと量を効率的か つ経済的に採掘運搬できる機動性のある超大型のダンプトラック 


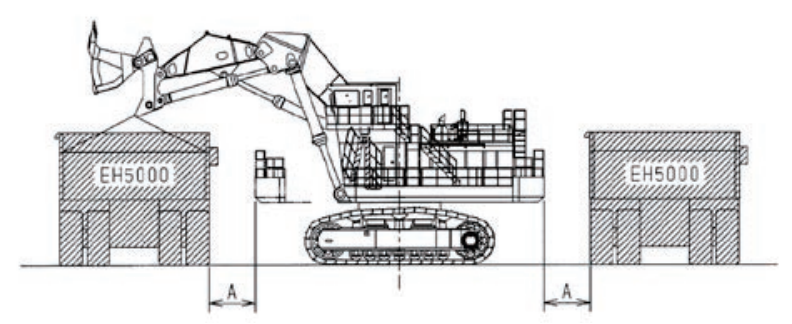

Fig.2 Distance between dump truck and EX8000 turning end radius at dump side loading.

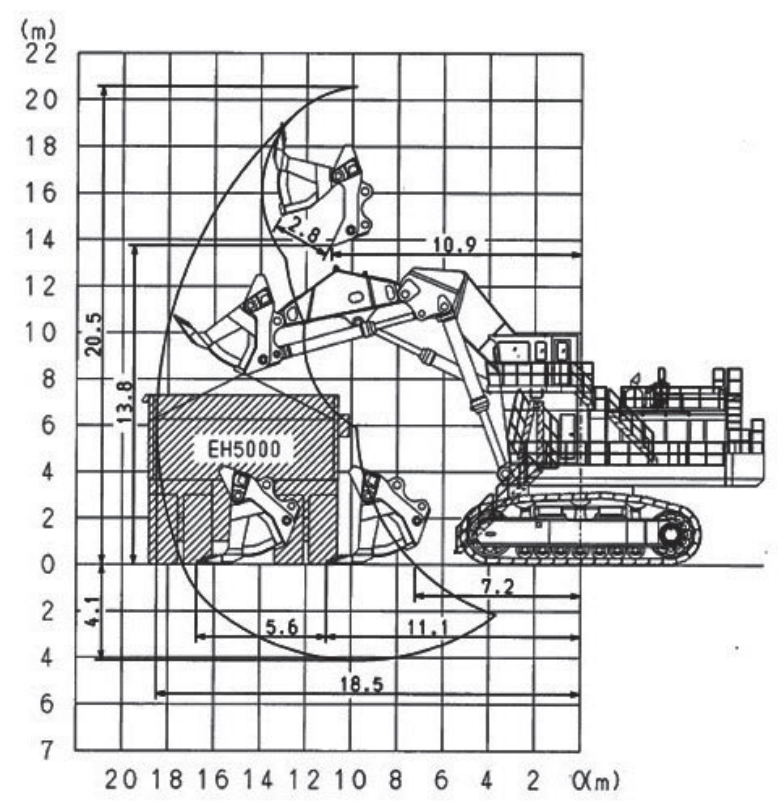

Fig.3 Working ranges

Table 1 Numbers of bucket loading per truck.

\begin{tabular}{|c|c|c|c|c|c|}
\hline & EH 3000 & EH 3500 & $\mathrm{EH} 4500$ & EH 5000 \\
\hline \multicolumn{2}{|c|}{$\begin{array}{ll}\text { Max.Pay Load } & \text { ton } \\
\end{array}$} & 157 & 193 & 255 & 293 \\
\hline \multicolumn{2}{|c|}{ Capacity $\mathrm{m}^{3}$} & 83 & 102 & 134 & 154 \\
\hline Model & Bucket Capacity & \multicolumn{4}{|c|}{ Numbers of bucket loading per truck } \\
\hline EX3600 & $20.0 \mathrm{~m}^{3}$ & 4.1 & 5.1 & 6.7 & \\
\hline EX5500 & $27.0 \mathrm{~m}^{3}$ & 3.1 & 3.8 & 5.0 & 5.7 \\
\hline EX8000 & $40.0 \mathrm{~m}^{3}$ & & & 3.4 & 3.8 \\
\hline
\end{tabular}

と油圧ショベルが中心となっている。

こうした背景から超大型ショベルの開発が必要になり，開発に 着手した。本報では, 開発した超大型ショベルの詳細と超大型ショ ベルによるオイルサンド鉱床開発について報告する。

\section{2. 超大型ショベルの開発}

開発の狙いは鉱山用積込機として最も望まれる卓越した信頼性 を確保するために下記に示す通りとした。

(1) オイルサンドの運搬の主力である 300ton 級ダンプにマッ チングするバケット容量，作業範囲とする。

(2) 車体搭載が可能で大作業量を達成できる新油圧システム を構築する。

(3) 車載ネットワークを用いたコントローラシステムとし， 予防保全実現のためのモニタリングシステムを構築する。

$2 \cdot 1$ (1)ダンプとのマッチング

Table 1 にEX8000 及び当社超大型ショベルのマッチングする ダンプへの積込み杯数を示す。

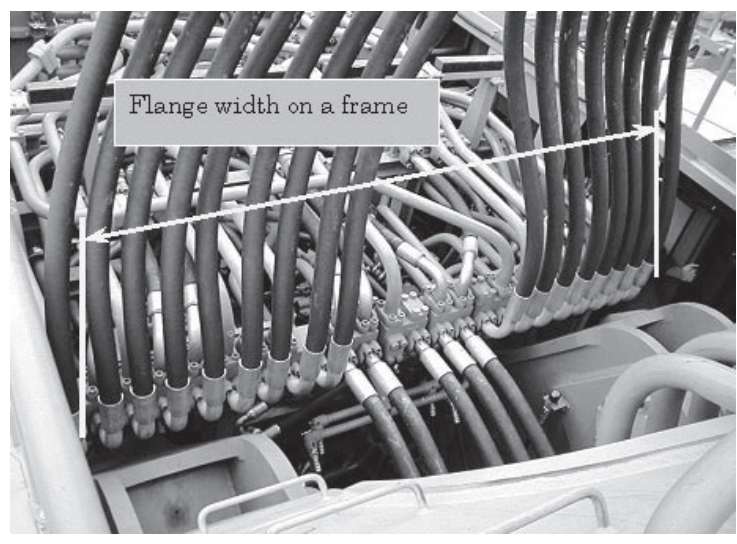

Fig.4 Hoses between the main frame and the front attachiment of EX5500.

ダンプの運用効率から 1 台への積込杯数は 4 ～ 5 杯がベストと 考えられ, EX8000 は当社 300ton 級のダンプEH5000 とのマッチ ングも考慮し, 約 4 杯で積込みできるよう, バケット容量を $40 \mathrm{~m}^{3}$ とした。

Fig. 2 にダブルサイドローディング時の, ダンプ積込時のベッ セル端部とEX8000の旋回後端半径との距離 A を示す。この Fig. 2 はリアバケットを鉛直にし, リアバケット下端がダンプ中 央部の位置において, 旋回後端半径とベッセル端部との距離を見 たものである。当然のことながら, ダンプ積込時にダンプとショ ベルとの車間をある一定距離とる必要がある。この距離が小さい とダンプ中央部よりリアバケット下端位置がショベル側に近くな り，実質の積込性に支障をきたすことになる。当社 300ton 級の ダンプ EH5000 との距離 $\mathrm{A}$ は $2.3 \mathrm{~m}$ と十分なレベルになるように, また, Fig. 3 に示すようにダンプの積込みに適切な作業範囲とな るよう最大掘削半径は $18.5 \mathrm{~m}$, 後端半径は約 $8.3 \mathrm{~m}$ とした。

さらに, ダンプへの積込みを楽に行なうためには適切なアイレ ベル（地上からの運転者の目視高さ）の確保も必要であり, ダン プのベッセルを見渡せるようにアイレベルを $9 \mathrm{~m}$ とした。

\section{$2 \cdot 2$ (2)新油圧システム}

これまで超大型ショベルは機械の大型化に伴い，コントロール バルブ数を増やして対応してきたが, 配置上EX5500（全装備質 量 518 ton, バケット容量 $27 \mathrm{~m}^{3}$ ) 搭載のコントロールバルブ数 6 ケ が限界となっていた。同様の考え方では EX8000 の場合, コント ロールバルブ数は 8 ケ, スプール数で 32 本となり, これまでの ようなバルブ数の増加による対応では 800ton 級ショベルのシス テム開発は困難となった。

Fig.4 に EX5500 の本体一フロント間ホースを示す。

大作業量を達成するために, 既存機と同等の掘削, 旋回, 放土 といったサイクルタイムを実現したいという狙いも本システム開 発の目的である。

そこで, システムの構想として, コントロールバルブの搭載が 困難な問題については，本体回路の簡素化を図ることにした。コ ントロールバルブシステムとは別の供給ラインを備え, 流量をア シストする分散メータインと呼ぶシステムを構成した。Fig. 5 に 構成を示す。

また，サイクルタイムを速くするためにシリンダからの戻り流 量を再生し高速化を図った。フロント自重により出ロポート側に 高圧が立つシリンダの場合, その圧油を再生することで大流量化 が図れる分散メイクアップと呼ぶシステムを構成した。メイク アップは自己の保持圧より流量を再生していることから動力を必 要とせずエネルギー的にも好適である。Fig. 6 に分散メイクアッ 


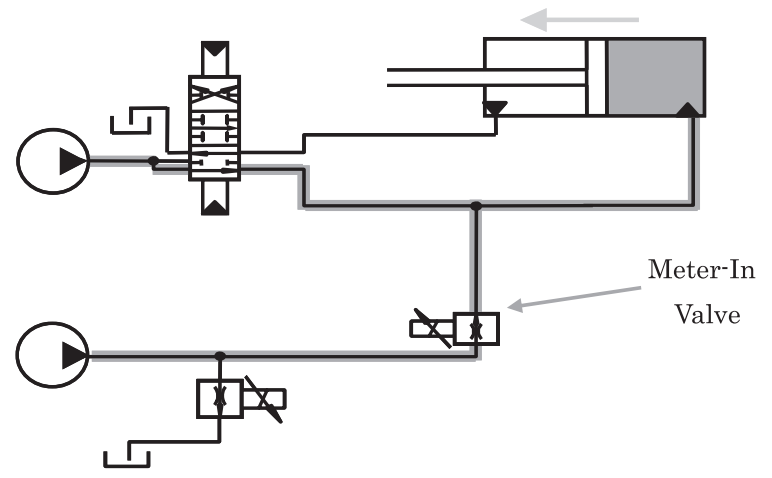

Fig.5 Constitution of Meter-In valve system.

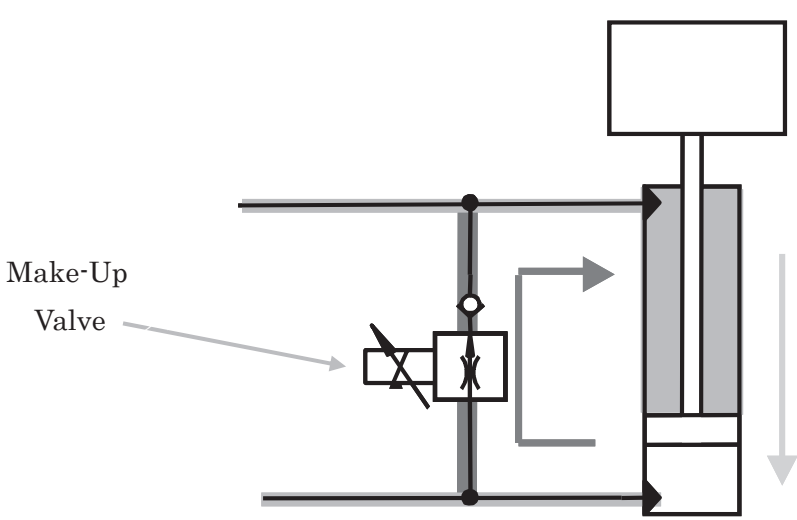

Fig.6 Constitution of Make-up valve system.

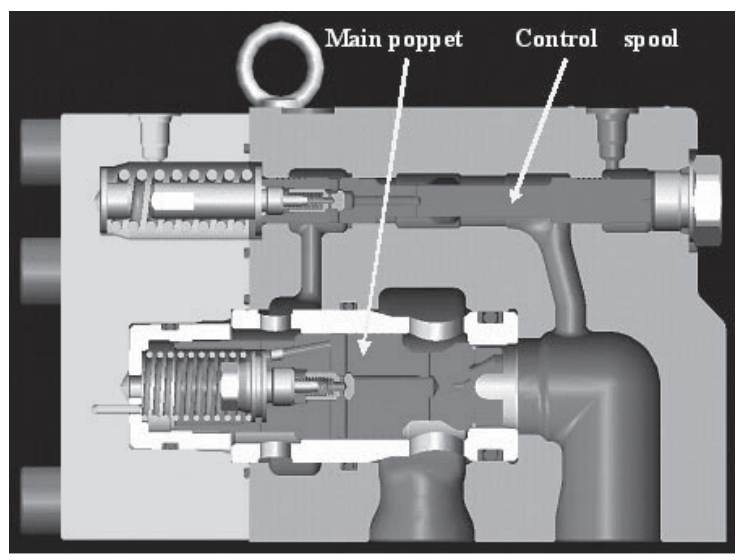

Fig.7 Proportional seat valve.

プの構成を示す。

以上のようなシステムを流量応援型分散バルブシステムと呼ん でおり，このシステムは比較的簡単な構成のバルブをフロントア タッチメントに分散配置し, 流量をアシストすることが大きな特 徵である。

メータイン及びメイクアップバルブは，シリンダポートに備えら れ, Fig. 7 に示寸比例シート弁を開発した。この比例シート弁は, メインとなる主弁とそれを制御する制御弁とからなっており，制 御弁の制御量に応じて主弁が制御されるポペット型の大流量を供 給できるバルブである。

\section{$2 \cdot 3$ (3)モニタリングシステム}

超大型ショベル等マイニング機用モニタリングシステムは, Fig. 8 のモニタリングシステム開発フローに示すように最終的に は予防保全実現を目標に開発を進めている。

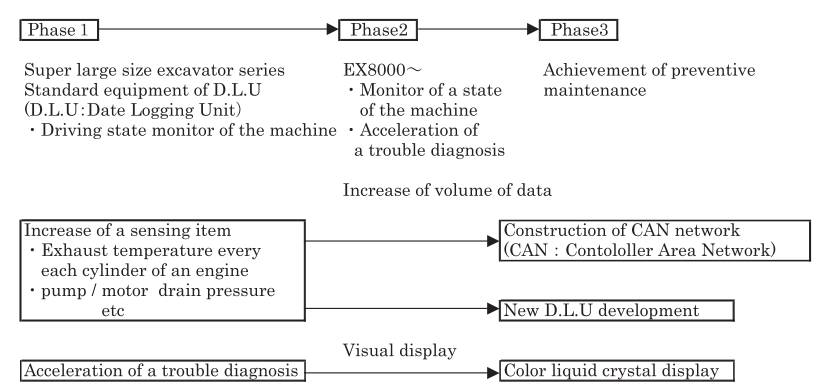

Fig.8 Development flow of monitoring system.

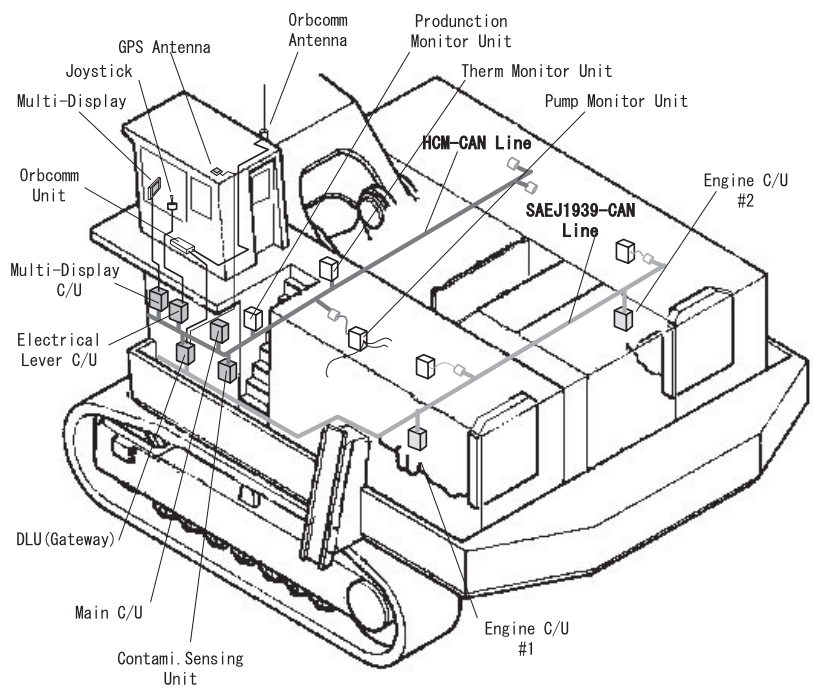

Fig.9 Contoroller Network.

これまでの当社における超大型ショベルシリーズでは,

D.L.U（データロギングユニット）を標準搭載し，車体の運転 状態の監視を行なってきた。EX8000では, 監視をさらに進め, 例えば，エンジンの各気筒毎の排気温度やポンプやモータ等の油 圧機器のドレン圧といったセンシング項目を大幅に増やし, 車体 の健康状態監視と故障診断の迅速化を狙った。

データ量の増大に対応するため, Fig. 9 に示すようなコント ロールエリアネットワーク (CAN) を構築した。

機能毎にコントローラを割り当て, 車体上に分散して配置した。 各々のコントローラは, CAN の通信ラインで接続されており, センシングデータをネットワーク上に流す構成となっている。

さらに, 故障診断の迅速化のためには, ビジュアル表示が不可久 となるため, Fig. 10 及び Fig. 11 に示す 10.4 インチの液晶ディス プレイを表示器に採用した。

Fig.11 に液晶ディスプレイの通常のメータと警報ランプ表示を 示す。警報ランプ点灯時は, 表示モードを切り換えることにより, Fig. 12 に示すような故障箇所をビジュアル表示することができ， 故障詳細部位及び対処方法も合わせて表示できる。

このような機能により，故障診断を迅速に行うことができる。 以上の狙いを実現してEX8000を開発した。

EX8000 の主仕様は下記に示す通りである。

$\begin{array}{ll}\text { ・ バケット容量 } & 40 \mathrm{~m}^{3} \\ \text { ・ 全装備質量 } & 805 \mathrm{ton} \\ \text { ・最大掘削半径 } & 18,500 \mathrm{~mm} \\ \text { ・ エンジン出力 } & 1400 \mathrm{kw} \times 2 \text { 基 } \\ \text { ・本体 全高 } & 9,900 \mathrm{~mm}\end{array}$

・バケット容量 $40 \mathrm{~m}^{3}$

・全装備質量

・エンジン出力 $1400 \mathrm{kw} \times 2$ 基 


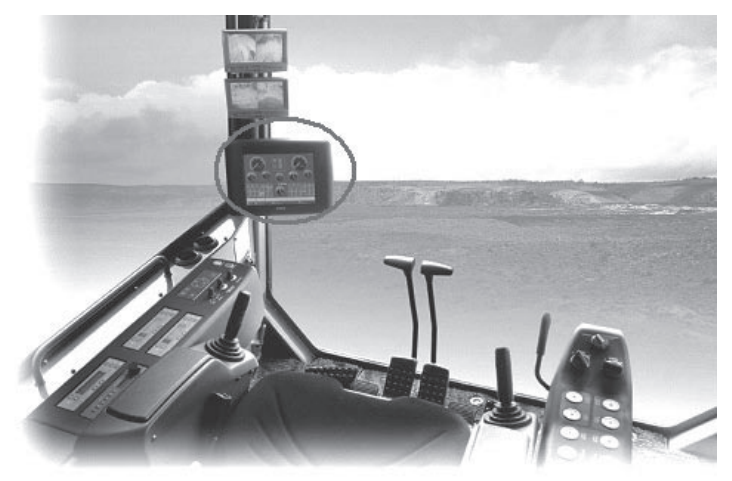

Fig.10 Liquid crystal display in driving room

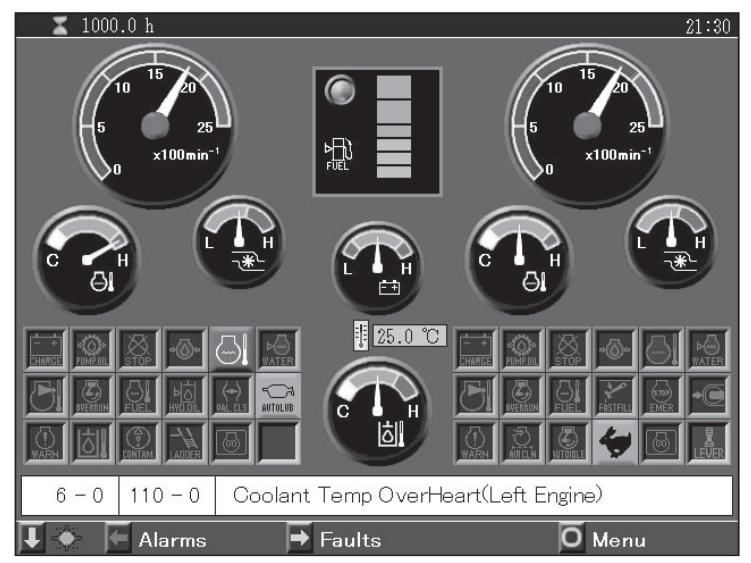

Fig.11 Liquid crystal display screen. (Meter and warning lamp display)

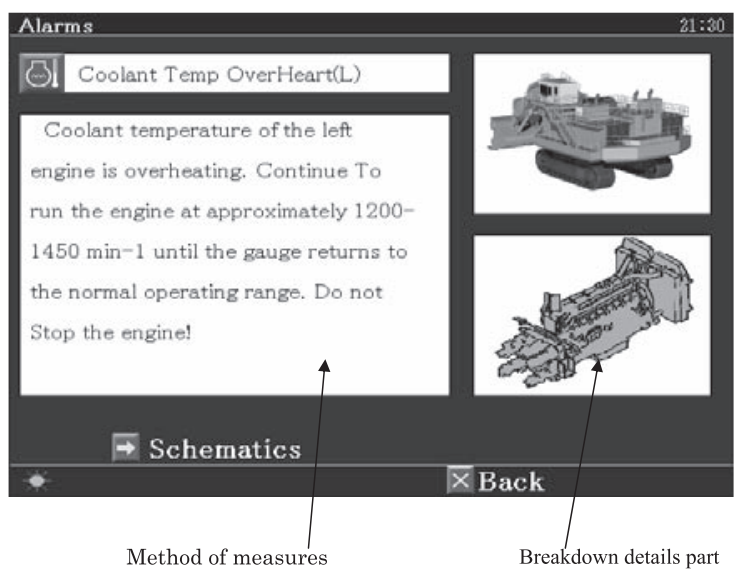

Fig.12 Liquid crystal display screen. (Visual display of locating fault)

Fig. 13 にEX8000 外観写真, Fig. 14 にEX8000 全体図を示す。

\section{3. 超大型ショベルによるオイルサンド鉱床の開発}

EX8000の稼衝地はカナディアンロッキーなどのあるアルバー タ州の北東に位置するフォートマクマレーのオイルサンド鉱山で ある。アルバータ州のオイルサンドは世界最大の石油埋蔵量を 誇っており，石油が砂と水，粘土の混合物の中に含まれている。 Fig. 15 にアルバータ州のオイルサンドの分布を示す。

このような膨大な資源ができたことを説明する最も有力な理論 は，ロッキー山脈を形作ったものと同じ圧力が，アルバータ州南 部にあった原油を北東に向けて流し込んだものと言われている。

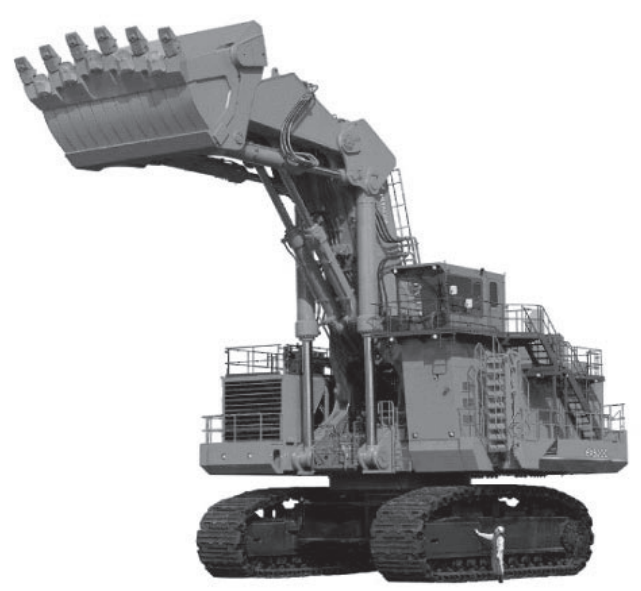

Fig.13 Photograph of EX8000.

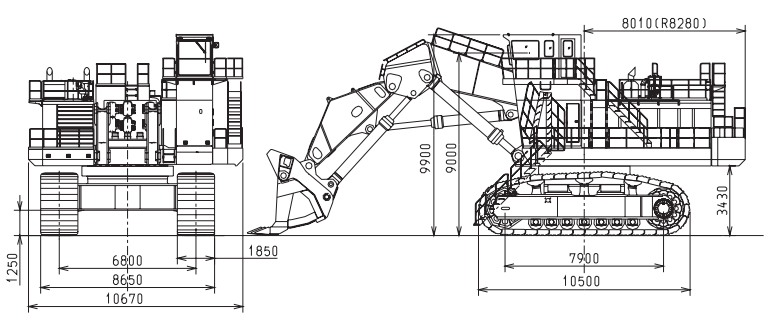

Fig.14 EX8000 scale.

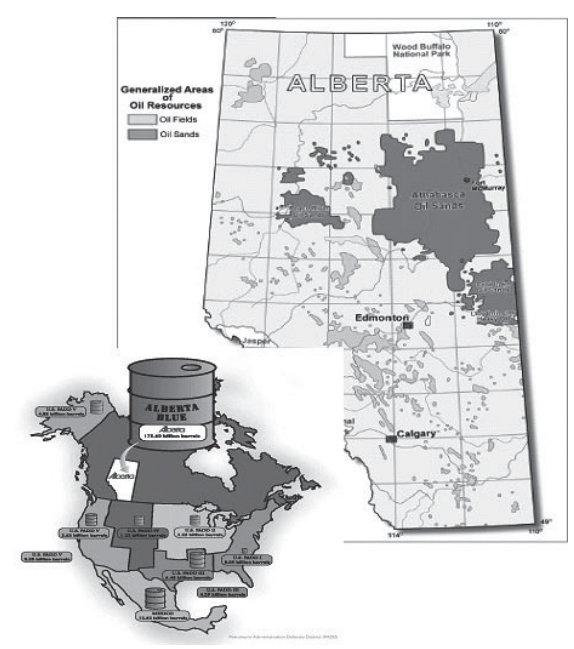

Fig.15 Distribution of oil sand of Alberta.

長い年月の間，水と細菌が作用し合い，それが砂とタールが混じ りあった形のビチュメン（瀝青．れきせい）という非常に重くそ して炭素分を含有するきわめて粘性の高い原油に変わっていっ た。太古の川の砂に滲み込んで残された石油は各地域に堆積され た。オイルサンドに含まれるビチュメンの割合は約 1 〜 20\%で ある。

Fig. 16 にオイルサンドから石油が精製される概略過程を示す。 抽出は，オイルサンドに熱湯を注ぎ砂と石油を分離させるとい う方法である。

オイルサンドに熱湯を注ぐとドロリとした懸濁液となる。懸濁 液は分離管に送られ, そこで砂, 水, ビチュメンの 3 層に分けら れる。ビチュメンは上層に浮かんでくるためすくい取られ，不純 物の除去と改質が行なわれる。 


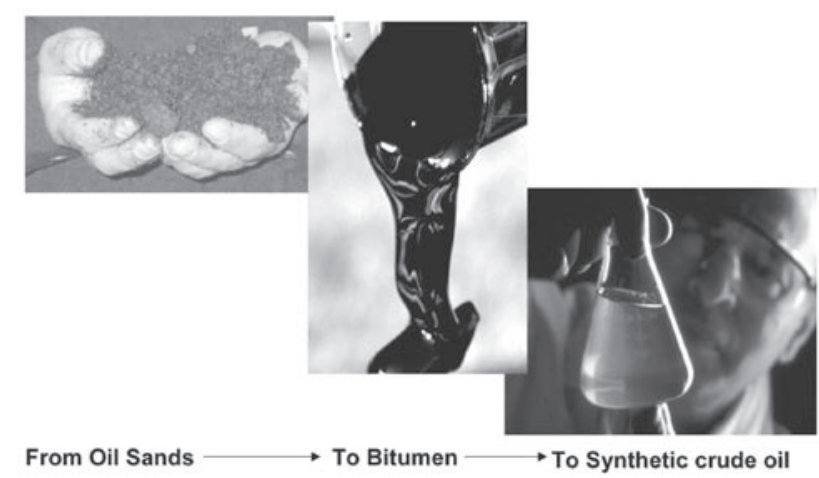

Fig.16 Outline process before becoming oil from oil sand.

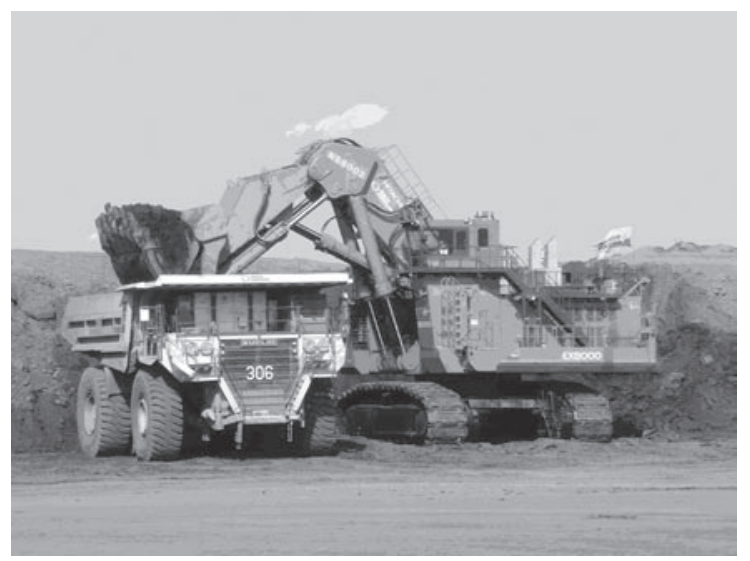

Fig.17 EX8000 which is operating in the oil sand spot.

小さな炭化水素分子と違ってビチュメンには炭素が多く水素が わずかしか含まれていない。改質とは，この分子の中の炭素をい くらか取り除き, 水素を加えることによって価值のある炭化水素 製品を作ることである。工程の最後には合成原油（Synthetic Cyude Oil）という製品になる。この原油は，2 トンのオイルサン ドからドラム午約 1 本分が抽出される。

フォートマクマレー近郊の大規模な鉱山は幾つかあり

その主たる鉱山及び鉱山会社は下記の通りである。
- Albian Sands 〜日産 16 万バレル

- Syncrude 〜日産 35 万バレル

· CNRL (Canadian Natural Resource Limited) 〜 今後 9 千億 円の投資予定。2010 年までに日産 30 万バレルを予定。

・Koch Oil 〜日産 13.5 万バレル

・ Suncor 〜日産 23 万バレル $\Rightarrow 2008$ 年までに 40 万バレル に増産予定。

オイルサンド採掘の工程は樹木の伐採，表土剥ぎ，そしてオイ ルサンドの掘削運搬と進行する。EX8000 は約 $10 \mathrm{~m}$ の表土層と約 90m のオイルサンド層の掘削, 積込み作業を行っている。この掘 削機械には, 真冬はマイナス 40 度になる極寒の寒さとコールター ルのような粘っこい重質な原油を含んだ砂の掘削作業に耐えられ る強勒さがもとめられる。Fig. 17 にオイルサンド現場で稼働中 の EX8000を示す。

採掘は休みなく 1 年中昼夜を通して行われ, 稼働体制は 2 シフ ト・23 h/日である。オイルサンドの運搬は $300 \sim 350 \mathrm{t}$ 級のダ ンプトラックが主力で使われている。掘削積込み作業は超大型油 圧ショベルで主に行っている。先に納入した EX5500（運転質量 $518 \mathrm{t}$, バケット容量 $27 \mathrm{~m}^{3}$ ) は上記 Albian Sands で稼働中であり, EX8000の 1 号機も Albian Sands，2 号機及び 3 号機は CNRL で 稼働中である。

\section{4.あとがき}

2006 年 9 月現在, EX8000の 1 号機及び 2 号機はカナダのオイ ルサンド現場で稼働中であり，稼働時間はそれぞれ約 10000 時間 と約 3000 時間に達する。3 号機も同現場にて 2006 年 9 月初めか ら稼働を開始している。

今後, 定期的なフォローアップを行い, 鉱山機械に求められる 高い信頼性の確保を図っていくことが重要である。

また，本文で記載したモニタリングシステムは，鉱山機械に要求 されるライフサイクルコスト低減のために非常に有効な手段であ るが，まだ完成したものとは考えていない。実機データの蓄積を 継続し, 予防保全の確立を図っていく所存である。

\section{References}

1) Manual issued at oil Sand discovery center by community development of Alberta. 